\title{
IMPLEMENTATION OF ACTION RESEARCH IN EDUCATIONAL INSTITUTION
}

UZMA ZAIDI'

Princess Nourah Bint Abdulrahman University, Riyadh, Saudi Arabia

\section{ABSTRACT}

The study aimed to implement action research method in educational institution for the sake of positive reforms and to initiate process of progress by using combination of Organizational Psychology and Administration. It is observed that those educational institutions who do not meet the needs of advanced technology and serve with limited capacity gradually lose their position. The organizational research strategies discussed in this study were applied by author during Feb, 2011-Aug,2012 while performing the duties as Head of the Department at Applied Psychology, Islamia University Bahawalpur, Pakistan. The implementations could be helpful to apply these strategies in similar or other various fields.

\section{JEL CLASSIFICATION \& KEYWORDS}

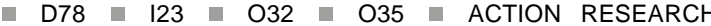
EDUCATIONAL INSTITUTION ORGANIZATIONAL PSYCHOLOGY

\section{INTRODUCTION}

Action Research are usually implemented in business, industry or commercial growth. This research method could be beneficial if used in other disciplines innovatively. In current study applied research methods and strategies are used in educational institutional department.

\section{Educational Institution}

Islamia University of Bahawalpur, Pakistan (formerly known as Jamia Abbasia) was declared as a general University in 1975, and was renamed as The Islamia University of Bahawalpur. Currently, it has four main campuses.

of Bagdadul Jadeed is the largest campus situated in Bahawalpur having 45 departments offering 74 disciplines (IUB, 2014). Author was appointed as Head of the Department in Applied Psychology during Feb, 2012, this department was established in July, 2000. Department was offering two degree programs of BS and MSc in psychology and one postmasters diploma in counselling psychology. There was no major contribution of the department toward community service and to enhance toward specializations of applied psychology programs. In the area of Southern Punjab there are only two universities offering Masters leve education in Psychology. Usually students has to travel to other far off areas of country if they opt to go toward MPhil or PhD program.

In the above mentioned scenario, it seems quite challenging task that require extra ordinary efforts. Author has experience to work as team coordinator for collaborated venture of Anti Narcotic Force Pakistan, United Nations Drug Control Program and Drug Advisory Program of Colombo Plan (Oct, 2002 - Dec, 2005). So after reviewing and conducting situational analysis, it was assumed to adapt organizational strategies those could precipitate progress of department and staff as well. In order to achieve

' uazaidi@pnu.edu.sa

www.journals.cz these goals, implementation of action research was considered as best.

\section{Action Research}

Action research usually involves a small scale intervention on the part of the researcher in the phenomenon being studied. Thus in this research paradigm the researcher becomes actively involved with the situation or phenomenon being researched (Aguinis, 1993; Ledford \& Mohrman, 1993). The concept action research based upon Kurt Lewin's (1946) work. According to him:

"The research needed for social practice can best be characterized as research for social management or social engineering. It is a type of action-research, a comparative research on the conditions and effects of various forms of social action, and research leading to social action. Research that produces nothing but books will not suffice" (Lewin 1946)

Action research is participatory and very specific. An important feature of action research is that it is selfevaluative. It is most important for this type of research for the researcher to be aware of the impact which his/her presence has on the situation. Depending on the circumstances, quantitative or qualitative analytical techniques may be required to analyse the evidence being collected. This approach which is also sometimes referred to or closely related to participant observer research, is relatively new but its popularity is increasing.

There are some certain steps to follow while conducting action research. An observation is the first element of the action research process that is the "Ideological Perspective". The second element "Fact-finding" is significant in the way that a measurable facts are essential to support those statement in order to reduce to the minimum the perceptions gaps and context difference. The third element "Goal structuring" could be achieved by feedback (Gill \& Johnson, 1991). Fourth step is "Action Strategies", the level of structure of goals will determine the action strategies. The deliberated diagnosis, prescription and therapy associated with action learning thus makes (a) deciding, (b) learning and (c) advising all three aspects of the same essential and logical process - the application of the scientific method to changing real systems managed by real people. Objectives of the action learning study can be achieved through following steps:

Step 1: Determine the problem (collect baseline data) and the desired outcome

Step 2: Identify some possible solutions

Step 3: Implement a potential solution and collect data

Step 4: Analyse the data and reflect on the effectiveness of the strategy

Step 5: Repeat steps 3 \& 4 as needed

However, it is recommended by researchers to choose the strategies that allow the maximum of cycles of Action 
Research cycles. Here is a figure explaining the process of action learning method:

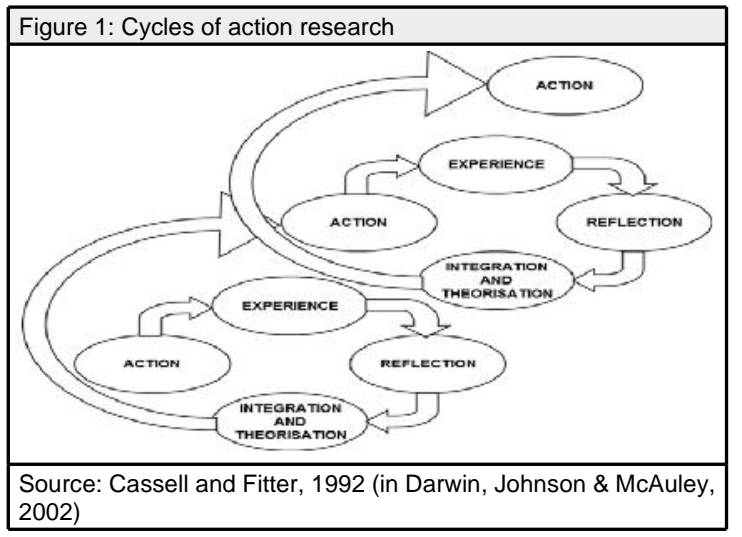

Revans (1983), identifies five successive stages (observation, provisional hypothesis, trial, audit and review) and is identical to those of:

- The rational decision (survey, first decision, pilot run, evaluation and final decision).

- The learning sequence (awareness of ignorance, new idea, taking a chance, watching effect, remembering for next time)

- The advisory argument, either given or received (admission of need, choice of counsel, test of confidence by action, estimate of outcome, confirmation or rejection of counsel).

Action learning teams may be formed for the purpose of handling either a single project or several projects (Marquardt, 2004). In team-project action learning, participants work on solving a single project. In this type of action learning, both team members and a project are usually determined by the organization. In contrast, in individual-project action learning, participants bring in their individual projects to the team to solve problems at work with the help of team members. In rare cases (Cho, 2013), team-project and individual-project action learning are combined in an action learning program (titled "dual-project action learning") to balance action and learning in the action learning process. A dual-project action learning program requires that participants carry out both team and individual projects.

\section{Objectives}

The aim of the study is to identify the root problems causing hurdles in the expansion and growth of department. Anothe major objective was to create insight of the problem among stakeholders (mainly staff members) and then to find out solution and implementation by themselves. Action research provide a solid base toward enhancement of independent problem solving skills on organizational level.

\section{Situational Analysis}

It was necessary to work on first phase of action learning 'to develop rapport' and provide the environment of mutual understanding of staff and administration. It was the great opportunity to utilize the knowledge and the bring change in positive direction because this was the only way to overcome the frustration of employees and to develop the change in the culture of organization. For this purpose an idea was launched to conduct seminar on 'Mental Health' (May 10, 2011). All the staff members involved in various committees and their moral was boosted during this activity.
Event management also become the source of reducing interpersonal conflicts as well. After getting initial observations, some essential measures were taken e.g., attractiveness of institution (Table 1) was conducted.

Table 1: Rating Scale to measure the attractiveness of the institution (How attractive is institution)

\begin{tabular}{|l|l|l|}
\hline Groups & Rating $^{*}$ & Explanation \\
\hline Students & 3 & $\begin{array}{l}\text { Department is not offering } \\
\text { specializations and higher degree } \\
\text { programs; uncertainty of job } \\
\text { opportunities }\end{array}$ \\
\hline Employees & 3 & $\begin{array}{l}\text { Gap of communication between } \\
\text { administration and employees; not } \\
\text { involved in decisional process }\end{array}$ \\
\hline Allied Colleges & 2 & $\begin{array}{l}\text { Feeling deprived due to lack of } \\
\text { autonomous rights and updated } \\
\text { information en promams, }\end{array}$ \\
\hline Administration & 3 & $\begin{array}{l}\text { Not enhancing its programs } \\
\text { community work and quality of work }\end{array}$ \\
\hline
\end{tabular}

Scale of 1-5: 1: very unattractive; 2 : unattractive; 3 : Neutral; 4: attractive; 5 : extremely attractive

Source: Author

For above mentioned table evaluation form were used to gather rating information. It is clearly seen that with all the groups, there are multiple reasons of not being satisfied with the overall progress. Here is a brief summary of identified risk/problem and its possible solution/ strategies (Table 2).

\begin{tabular}{|l|l|l|}
\hline \multicolumn{3}{|l|}{ Table 2: Summary of Action Learning } \\
\hline Identified Risk & $\begin{array}{l}\text { Target } \\
\text { population }\end{array}$ & Strategies \\
\hline $\begin{array}{l}\text { Lack of commitment } \\
\text { Lake of motivation } \\
\text { Role culture }\end{array}$ & $\begin{array}{l}\text { Staff } \\
\text { Students }\end{array}$ & $\begin{array}{l}\text { Action Leaning } \\
\text { Team Leadership model } \\
\text { Task Culture }\end{array}$ \\
\hline $\begin{array}{l}\text { Apprehension toward } \\
\text { future } \\
\text { Lack of Innovation/ } \\
\text { development } \\
\text { Resistance to change }\end{array}$ & Staff & $\begin{array}{l}\text { Capacity building for new } \\
\text { programs } \\
\text { Periodic trainings }\end{array}$ \\
\hline $\begin{array}{l}\text { Non avalibility of } \\
\text { Social responsibility }\end{array}$ & Community & $\begin{array}{l}\text { Capacity building for } \\
\text { counseling center }\end{array}$ \\
\hline $\begin{array}{l}\text { Feeling of being } \\
\text { ignored }\end{array}$ & $\begin{array}{l}\text { Allied } \\
\text { colleges }\end{array}$ & $\begin{array}{l}\text { Continuous communication } \\
\text { Visits }\end{array}$ \\
\hline Source: Author & \multicolumn{2}{|l}{} \\
\hline
\end{tabular}

\section{Action Research Process}

Regularly conducted weekly meeting provided to develop new strategies and to check the progress or failure of previously implemented actions. This was done to acquire direct overview and observation of the situation before applying action research process. During the first few weeks, the team clarifies the output of the project, got lessons for problem-solving skills. The team analysed the previous and present reports received from Quality assurance cell. Action learning process was conducted, followed the three stages of preparation, team meetings, and follow-up activities (Cho \& Bong, 2013; Miller, 2003). All the step were followed according to the process in order to get the targets.

i. Preparation

As a first step, administration was informed before launching an action learning project. Revans (1982) has emphasized the significance of a "structure of welcome" before setting up meetings because building trust and rapport between participants and organizations is the key to success in action learning. Initial efforts for building trust and openness and securing management support lead individuals and organizations to further engagement 
in an action learning project (Edmonstone, 2011). An orientation session enacted in this preparation stage helps participants better understand how action learning progresses by providing information about the action learning process and ground rules for teamwork. At this step meetings were arranged with Deanship, head of the department and staff members to develop rapport, to communicate the upcoming problem solving process and to gather their views. During this procedure the resistance of employees reduced to adapt changes. Hierarchy also showed their interest and support in action learning process to overcome the problems.

\section{ii. Team Meetings}

Action learning projects are work-based and difficult to solve alone (Revans, 2011). In the team meetings stage, action learning practitioners deal with the project and team selection, roles of a learning coach, problemsolving processes, reflection, and organizational support. In the team selection, team members with diverse backgrounds are highly desired because participants of diversity can generate innovative ideas and explore different solutions. Revans's (1982) concept of "comrades in adversity" implies that participants form a collective spirit through hardships in solving difficult issues at work in the action learning process. However, sometimes active involvement in the action learning process may hinder participants' due to the team leader's authority and organizational power and politics. (Ram \& Trehan, 2009). Three members were selected as a team to work as a coordinator of degree programs to work with learning coach. Learning coaches help participants learn the content of the project and problemsolving process using questions, feedback, and reflection in the action learning process. Identified risk factor were discussed with team members and with mutua agreement it was decided to target the population of students, staff and community. It was also discussed that to move from minor issue to major. It was necessary because when we want to change the culture of an organization usually it is recommended practice to move in said manner. In order to bring change in behaviour, first we target to change in feelings and thought by conducting periodic training workshops, seminars and discussion forums for students and staff. This also provide a platforms to them to rebuild their skills, expertise, social relationship and to enhance their self-esteem, self-respect, trust in institution and ultimately motivation and commitment. Moreover capacity building process for MS in clinical psychology and Executive Master's program for professional was initiated. Capacity building for departmental based counselling centre was also started. Student of freshly enrolled MS program were having key holding position in this project. allied colleges were invited in various ceremonial activities and both way open ended communication was build. These positive psychological factors contribute to accept the openness toward change. Afterwards thorough their team leaders the overall progress of department was conveyed to staff which eventually reduced the apprehensions and to set their short term and long term targets accordingly.

In the team meetings stage, reflection creates learning grounded in past and current experiences, and makes action and learning stronger in action learning teams (Reynolds, 2011). Through reflection, action learning teams can convert tacit knowledge into explicit knowledge and improve their thinking and solutions to challenges that the teams face. So reflection was gathered by team members and by direct feedback of coordinators of different departments. Horizontal communication was introduced to coordinators. Though initially it was bit difficult and burdensome for them. Gradually, it was realized at organizational level that problem solution become more easier.

Sponsors play a critical role in action learning including the selection of action learning projects and participants, clarification of the outputs, communication with stakeholders (e.g., Administrators), motivation of participants, provision of physical and personnel resources, and decisions regarding implementation and follow-up activities. Deanship, head of the department and team leaders as sponsors support participants throughout the action learning process were involved, which led to the department's performance toward improvement and task culture.

\section{iii. Follow-up Activities}

In the follow-up activities stage, organizations (sponsors) made a decision on the implementation of action learning teams' solutions at the final team presentations. Participants share their solutions and lessons learned from their action learning process with other organizational members through annual action learning conferences and knowledge management systems (e.g., intranets) in the organization. These communication channels are outstanding venues in which organizational members can share key success factors of action learning practice. Depending on the context, learning environments may take several forms in action learning practice. Face-to-face action learning teams are most common in the cases identified (Park, Kang, Valencic, \& Cho, 2012). Increased use of technology in action learning opens many possibilities concerning how blended learning contributes to undertaking new learning platforms, motivating participants, and encouraging reflection in different contexts as well as meeting the immediate needs of busy executives.

\section{Discussion}

Through Action Learning processes staff started work in collaboration with management. This collaboration enabled them to engage successfully in the exploration of problems and to generate solutions from each other and eventually it was beneficial not only for them but for organization too. It was a great experience to observe real work challenges and to sought solutions with team. Action learning process was implemented within institution, as discussed earlier, having the procedure of action learning as preparation, meetings, and follow up activities. This activity allowed to analyse the personal and professional growth, as well as to develop a better sense of understanding of institutional structure and action learning method. It also provides a good chance to view the theoretical background in action. In result, with the application of action leaning strategies, essential and identified area of risk were managed. This task also refined author's ideas related to initially developed concepts related to organizational culture.

All the identified risk factors related to students, staff and community were settled by using different strategies. institution started to expend its affiliation with other significant professional bodies, and associations. As department got professional membership of ICPT for students. Regular meetings as well as trainings were arranged for staff and students. Quality assurance activities were improved. Development of counselling centre for students provide optimistic view to enhance counselling 
service for community. New programs for the promotion of education and Community Development were started. Overall, action research helped to achieve initially set targets with period of (Feb, 2011-Feb, 2012) one year to improve its performance.

\section{Conclusion}

Researcher implemented the action learning process as discussed earlier in the chapter of methodology having the procedure of action learning as preparation, meetings, and follow up activities. In result, with the application of above mentioned strategies, essential and identified area of risk are managed. As Revans (2011), put it simply, "There is no action without learning and there is no learning without action". Application of action research can be helpful to identify the risks and to resolve the organizational issue within the potential of members without spending extra time and energy, is possible.

\section{Acknowledgements}

I am thankful to all the administrative personal of University and team members who believe that knowledge is power.

\section{References}

Aguinis, H. (1993). Action research and scientific method: Presumed discrepancies and actual similarities. Journal of Applied Behavioural Science, 29(4), 416-431.

Cassell, C., \& Fitter, M. (1992). Cyclic Process in action in J. Darwin, P. Johnson, \& J. McAuley, (2002). Developing Strategies for change. Harlow FT: Prentice Hall.

Cho, Y. (2013). What is Action Learning? Components, Types, Processes, Issues, and Research Agendas. Learning and Performance Quarterly, 1(4), 1-11.

Cho, Y., \& Bong, H. -C. (2013). Trends and issues in action learning practices: Lessons from South Korea. New York: Routledge.

Edmonstone, J. (2011). Action learning and organization development: Overlapping fields of practice. Action Learning: Research and Practice, 8, 89-97.

Gill, J., \& Johnson, P. (1991) Research Methods for Managers. London: Paul Chapman.

Islamia University of Bahawalpur. (2014). Overview. Retrieved November 12, 2014, from http://www.iub.edu.pk/overview.php

Ledford, G., \& Mohrman, S. (1993). Looking backward and forward at action research. Human Relations, 46 (11), 1349-1359.

Lewin, K. (1946). Action research and minority problems. Journal of social Issues, 2, 34-46.

Marquardt, M. J. (2004). Optimizing the power of action learning. Palo Alto, CA: Davies-Black Publishing.

Miller, P. (2003). Workplace learning by action learning: a practical example. Journal of Workplace Learning, 15(1),14-23.

Park, S., Kang, I., Valencic, T., \& Cho, Y. (2012). Why are we using action learning and in what contexts? Action Learning: Research and Practice, 10(1), 4-24.

Ram, M., \& Trehan, K. (2009). Critical by design: Enacting critical action learning in a small business context. Action Learning: Research and Practice, 6, 305-318.

Revans, R. (2011). ABC of action learning. Surrey, UK: Gower.

Revans, R. W. (1983). The ABC of action learning. Chartwell-Bratt, Bromley.

Revans, R. (1982). The origins and growth of action learning London: Chartwell- Bratt.

Reynolds, M. (2011). Reflective practice: Origins and interpretations. Action Learning: Research and Practice, 8, 5-13. 